\title{
Efficiency for Whom?: The Effect of Efficiency on Indonesian Islamic Commercial Bank's Deposit Return
}

\author{
Firdha Rahmiyanti \\ Islamic Economics Departement, Faculty of Islamic Studies, \\ University of Muhammadiyah Malang \\ E-mail: firdha.ry@gmail.com
}

\begin{abstract}
The main purpose of this paper is to examine the compliance of efficiency and deposit return in Indonesian Islamic commercial bank. The Sample includes an annual panel from 2005 to 2014. The data collected during the period 2005-2014 based on the annual report of Islamic banking that financial information is available. This research exclusively focus on commercial Islamic banking. To account for profit persistence, we apply a GMM technique to a panel secondary data which obtained from audited financial reports of 12 Indonesian Islamic Commercial banks in existence as at the end of 2015. The result of this study is that an efficiency on Islamic Commercial Bank's Deposit has a positive effect on deposit return.
\end{abstract}

Keyword: Efficiency, Deposit Return, and Islamic Commercial Bank.

\section{Introduction}

Rapid growing of Islamic finance is part of financial sector development and it is not restricted to Islamic countries and is spreading wherever there is sizeable Muslim community. A growing of more than $15 \%$ annually in the past five years for 250 financial institutions in over 45 countries practice some forms of Islamic finance. The market's current annual turnover is estimated to be $\$ 350$ billion, compared with a mere $\$ 5$ billion in 1985 . In the early 1970 s where Islamic banks firstly offered with different operational systems and attract researchers in conducting considerable research, focusing mainly on the viability, design, and operation of "deposit-accepting" financial institutions, namely basis of profit and loss sharing partnership rather than the payment or receipt of interest which extremely prohibited in Islam (Greuning and Iqbal, 2008).

Islamic banks commonly have two sources of funds. The first source is the public funds in bank deposits that comprises of Wadiah demand deposit, Mudharabah saving deposit, and Mudharabah time deposit. The second one is the 
public funds in non-bank deposits such as received financing, securities issued by banks, interbank liabilities, liabilities to the central bank, and other payables (Ismal, 2009). One of the many funds that product demand applies deposits mudharabah, where Islamic banks would act as (Fund Manager), while the customer acts as shahibul maal (owner of funds) in his capacity as will. Islamic banks can perform a wide range of kinds of business which does not conflict with the principles of Sharia as well as develop it buyers, Islamic banks will share the profits to the owners of the funds or the owner of the deposit in accordance with the agreed calculations (nisbah) and has poured in akad.

The magnitude of profit sharing earned, determined based on the success of the Fund Manager to generate a profit. The profit level of Islamic banks not only have an effect on the level of the result for the shareholders, but also for the effect on the results that can be given to clients who deposit funds (the concept of profit and loss sharing). Thus the ability of management to carry out their functions as a repository of wealth, businessmen and a good investment manager (professional investment manager) will largely determine the quality of his efforts as the intermediary institutions and its ability to generate earnings. (Apriandika: 2011).

Deregulation, consolidation and disintermediation are trends that have spurred a broad and long strand of academic research into the competitiveness, stability and efficiency of banks and banking markets. This strand of research covers scale and scope efficiency as well as X-efficiency (or managerial efficiency). Importantly, many studies find that for banks of all sires, X-efficiency appears to dominate both scale and scope efficiency (Berger et al., 1993).

Health levels, including the level of efficiency of the banking institutions can be assessed using a variety of indicators. One of the main sources of the indicators relied upon an assessment of the bank's financial statements is concerned. Based on the financial report of banking institutions can be calculated to have a number of financial ratios that can be used to predict the rate of profit, predicting the future, and to anticipate future conditions. (Halkos and Salamouris, 2004). In addition, according to Piesse (2000), Habib and Alexander (2000), Muhammad (2004) measurement of the efficiency of banking can be done with 3 other approaches; Data Envelopment Analysls (DEA), Stochastic Frontier Approach (SFA), dan Distribution Free Approach (DFA). This research will use the parametric method with use Stochastic Frontier Approach (SFA) to analyze the level of cost efficiency in Indonesia Islamic commercial banks.

So far there has been no research that explores the relationship of efficiency and deposit return, most researchers discuss about the comparative deposit return between Islamic banks and conventional banks. Beside that the tool to measure the efficiency of most still use BOPO ratio. This research conducted to find out and analyze the effect of efficiency against a deposit return rate of Islamic banking in Indonesia. And if the company proved to be efficient then the result, for whom the client or to the profit of the bank itself.

\section{Literatur Review}

According to Ismail (2011: 95) profit sharing was the allocation over the result of the effort which has been undertaken by parties that conduct that is party 
to the customer and the bank. In it there are two parties who conduct business, then the results of the efforts undertaken by both parties or one of the parties, shall be divided in accordance with the share of each party who did contract agreement. Level indicator for the results is the percentage for the results of customer deposits mudharabah received against the volume of deposits mudharabah.

One of the principles which applied Islamic bank is the application of the system profit sharing, if the amount of the profit is increased then the client received for profit will also increase, so also if the amount of profits decreased then for the results to the customer also decreased so that all the gains obtained be fair, whereas a conventional banking system in its operational principle is known by applying a system of interest (Riskya: 2015).

\section{Table 1.1: The Financial Ratio for Commercial Banks}

\begin{tabular}{|c|c|c|c|c|}
\hline Financial Ratio & $\mathbf{2 0 1 0}$ & $\mathbf{2 0 1 1}$ & $\mathbf{2 0 1 2}$ & $\mathbf{2 0 1 3}$ \\
\hline Deposit Return & 1.68 & 1.9 & 2.2 & \\
\hline Non Performing Financing & 3.02 & 2.52 & 2.22 & 2.62 \\
\hline Financing to Deposit Ratio & 89.67 & 88.94 & 100.00 & 100.32 \\
\hline Efficiency (BOPO) & 80.54 & 78.41 & 74.97 & 78.21 \\
\hline Capital Adequacy Ratio & 16.25 & 16.63 & 14.13 & 14.42 \\
\hline
\end{tabular}

Source: Bank Indonesia 2013

Based on the following table, in 2011 the deposit return experienced an increase of $0.22 \%$ compared with the previous year. This shows the magnitude of the net profit of the operational bank well developed. In fact, the magnitude of the FDR has decreased, meaning that financing channelled decline. However, the bank was able to minimize the troubled financing and improve the efficiency of the operational costs of the value of the NPF and the BOPO decreased.

This research examines the impact or effect of efficiency to deposit return Islamic banking in Indonesia. Based on the known researcher, there have been some previous research relating to efficiency and deposit return that authors use as a source of information and reference materials that are very useful. However, research on the effect of efficiency to deposit return islamic commercial banks particularly in Indonesia does not yet exist.

Cevik dan Charap (2011), studied the behavior of conventional and Islamic bank deposit return in Malaysia and Turkey. This research method using VAR and VECM from January 1997 to August 2010. Estimation results show that VECM models happen to short-term adjustment of the long-term, indicated by a significant error and Granger is worth negative either in Malaysia or Turkey. In the long term deposit rates to conventional bank strongly influenced the level of 
results for Islamic banks in Malaysia and Turkey. Analysis of FEVD explains that in Malaysia and Turkey in the long term, conventional bank deposit rate shocks bigger role against the fluctuation of the rate of return of Sharia bank deposits compared to the role of the rate of return of Sharia bank deposits in explaining fluctuations of conventional bank deposit rate.

Hichem Hamza (2015), studied does investment deposit return in Islamic banks reflect PLS principle. Hamza (2015) observing the compliance investment deposit products on the provisions of the Islamic Sharia in the sixty banks during the period 2004-2012 in 15 countries such as Indonesia, Malaysia, Saudi Arabia, Yemen, and other countries with a majority muslim population in others. The results show that the governance structure through the board of directors and Sharia board seems not to have an influence on the investment deposit return, however, they find that ownership concentration affects positively the Return on investment account holders (RIAH). Research Hypotheses:

$\mathrm{H} 0=$ Efficiency does not affect profitability

$\mathrm{H} 1$ = efficiency affects profitability

\section{Methodology}

In order to analyze the impact of Efficiency on The Deposit Return of Indonesian Islamic Commercial Banks, the study used two variables, one of them is the dependent and the others are independent variables. The control variables are comprised of bank-specific and macroeconomic determinants of bank deposit return. The data collected during the period 2005-2014 based on the annual report of Islamic banking that financial information is available. This research exclusively focus on commercial Islamic banking. To account for profit persistence, we apply a GMM technique to a panel secondary data which obtained from audited financial reports of 12 Indonesian Islamic Commercial banks in existence as at the end of 2015. The crosssectional element is reflected by the different banks in Indonesia and the time series element is reflected in the period of study (2005 - 2014). To know the impact of efficiency on profitability of Islamic Commercial banks then use a classic assumption Hausman test. To specify the random effects or fixed effects regressions. 
Table 1.2. Dependent and independents variables.

\begin{tabular}{|c|l|l|}
\hline \multicolumn{1}{|c|}{ Variabel } & \multicolumn{1}{|c|}{ Definition } & \multicolumn{1}{|c|}{ Measurement } \\
\hline Dependent Variable & \multicolumn{1}{|c|}{} \\
\hline Deposit Return & $\begin{array}{l}\text { Return on investment account holders (bagi } \\
\text { hasil untuk investor deposito) }\end{array}$ & Return on investment account holders \\
\hline Independent Variable & \multicolumn{1}{|c|}{$\begin{array}{l}\text { Production approach, intermediation approach, } \\
\text { asset approach, operating approach, and } \\
\text { revenue approach }\end{array}$} & Stochastic Frontier Approach (SFA) \\
\hline Efficiency & Financing to Deposit Ratio & $\begin{array}{l}\text { Total financing/investment account } \\
\text { holders }\end{array}$ \\
\hline FDR & Capital Adequacy Ratio & Equity/total assets \\
\hline CAR & Non Performing Financing & Net profit/Total assets \\
\hline NPF & Gross Domestic Product & GDP Growth \\
\hline GDP & Inflation & Annual average rate of inflation \\
\hline INF & &
\end{tabular}

FALAH Jurnal Ekonomi Syariah 
Research result indicates that the variable CAR, NPF, and FDR are the factors that affect the deposit return on Indonesian Islamic commercial banks (Rahma: 2015). And from the side of macroeconomics, there is inflation and gross domestic product which is a factor that affects the deposit return. I suppose that the improvement of economic conditions and the increase of investment opportunities could improve bank income and profits.

\subsection{Research Model}

To complete the aim and objectives of this study, the general model to be estimated is of the following linear form:

$$
Y_{i t}=\alpha_{o}+\beta \text { Efficiency }_{i t}+\sum_{j=1}^{k} X_{j} \beta_{j i t}+\sum_{m=1}^{m} \pi_{m} \mu_{m t}+\varepsilon_{i t}
$$

Variable, their Proxies and Symbols

Symbols Variables Proxies

$Y_{i t}=$ Deposit Return

\section{Explanatory Variables}

$\beta$ Efficiency $y_{i t}=$ Efficiency

$\sum_{j=1}^{k} X_{j} \beta_{j i t}=$ Bank Specific

$\sum_{m=1}^{M} \pi_{m} \mu_{m t}=$ Macroeconomic determinant

\section{Table 1.3: Hausman Test}

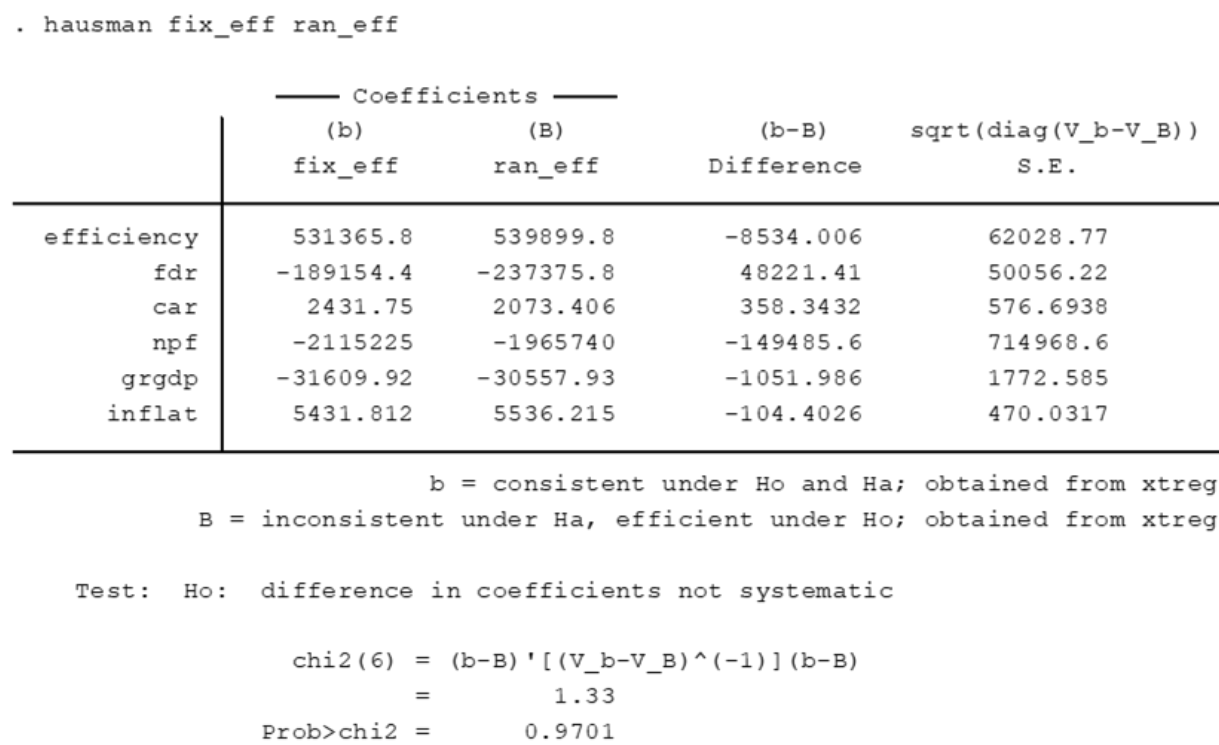


Based on Hausman Test results where p-value (Prob> Chi2) <Alpha 0.05 then $\mathrm{H} 1$ is rejected or which means the best choice is to use RE (Random Effect) instead of FE (Fixed Effect).

\subsection{Classic Assumption Test}

Table 1.4. Pairwise Pearson correlation coefficients.

\begin{tabular}{r|rrrrrrr} 
& IIBagi D effici y & fdr & car & npf & grgdp & inflat \\
\hline IIBagihasi D & 1.0000 & & & & & & \\
efficiency & 0.3628 & 1.0000 & & & & & \\
fdr & -0.1395 & 0.3728 & 1.0000 & & & & \\
Car & -0.2614 & -0.5904 & 0.1308 & 1.0000 & & & \\
npf & 0.0251 & 0.2254 & 0.2835 & -0.0474 & 1.0000 & & \\
grgdp & -0.1215 & 0.0073 & 0.0550 & 0.0348 & -0.0814 & 1.0000 & \\
inflat & 0.0660 & -0.0444 & -0.0061 & 0.0383 & 0.0476 & -0.0170 & 1.0000
\end{tabular}

The values above show the correlation between variables, where $\mathrm{X} 1$ in the efficiency column with $\mathrm{X} 2$ in the row fdr correlation value of 0.3728 . Expressed accept $\mathrm{H} 0$ or no problem Multicollinearity if the value of correlation between variables not more than 0.70 .

\section{Table 1.5: Summary Statistic}

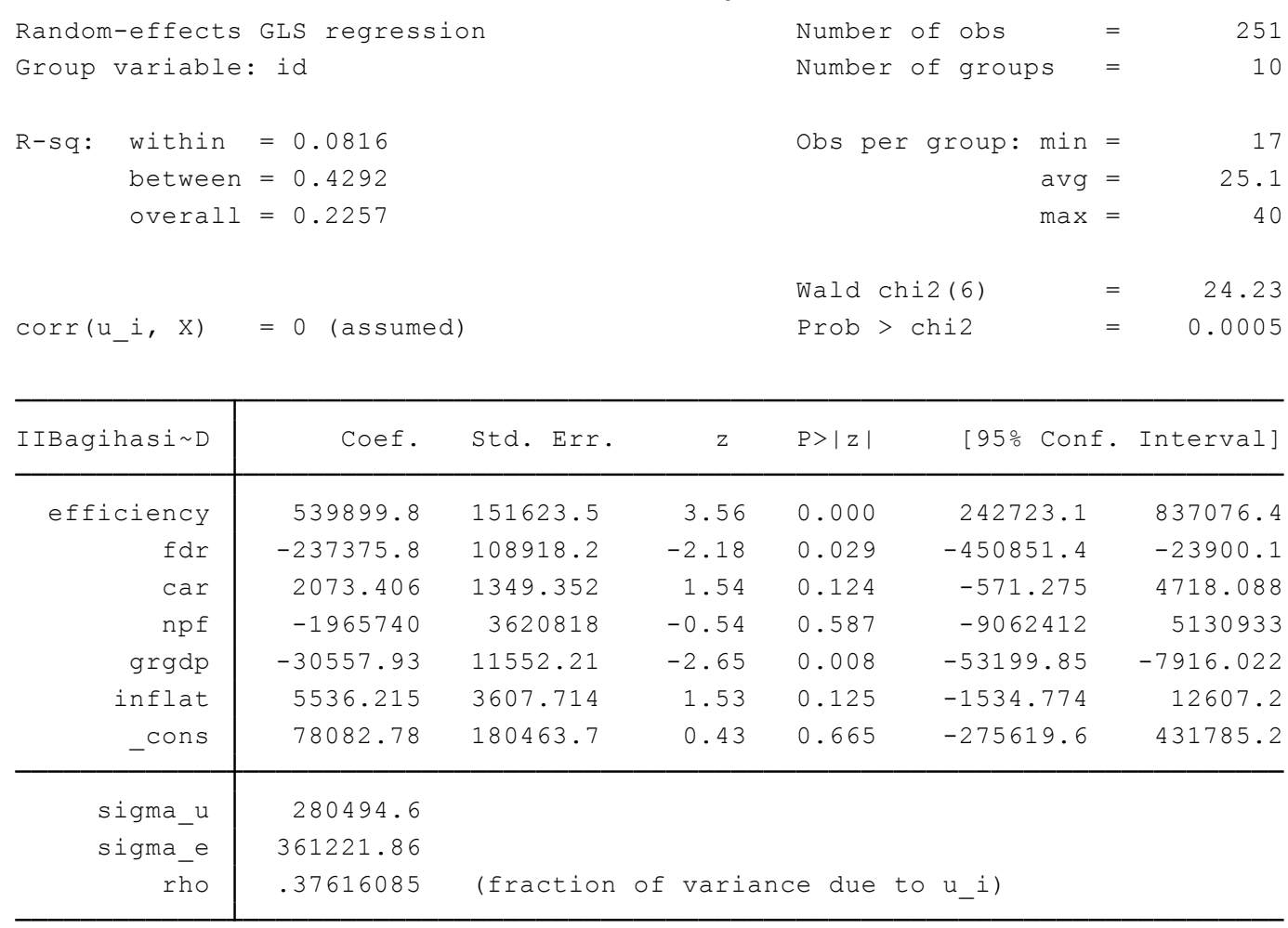


Based on the test results obtained the value of $\mathrm{z}$ score of 3.35 with sig. $\mathrm{Z}$ of 0.000 ( $p<0.05)$ so his decision rejected Ho. From the above regression results are known significance value of 0.000 which means all independent variables can explain dependent simultaneously.

\subsection{Coefficient of Determination $\left(\mathbf{R}^{2}\right)$}

From the test results obtained coefficient of determination of 0.0816 which means that the regression model contributes to the deposit return of $8.16 \%$ while the rest of $91.84 \%$ influenced by variants outside the model. 
Table 1.6: Results of GMM estimation.

\begin{tabular}{|c|c|c|c|c|}
\hline VARIABLES & $\begin{array}{c}\text { (1) } \\
\text { II Profit sharing for } \\
\text { Investor D }\end{array}$ & $\begin{array}{c}\text { (2) } \\
\text { II Profit sharing for } \\
\text { Investor D } \\
\end{array}$ & $\begin{array}{c}\text { (3) } \\
\text { II Profit sharing for } \\
\text { Investor D } \\
\end{array}$ & $\begin{array}{c}(4) \\
\text { II Profit sharing for } \\
\text { Investor D } \\
\end{array}$ \\
\hline efficiency & $\begin{array}{c}296,316.038 * * * \\
(102,395.871)\end{array}$ & $\begin{array}{c}522,356.705 * * * \\
(150,189.700)\end{array}$ & $\begin{array}{c}530,946.818 * * * \\
(149,951.494)\end{array}$ & $\begin{array}{c}539,899.766 * * * \\
(151,623.518)\end{array}$ \\
\hline $\mathrm{fdr}$ & & $\begin{array}{c}-285,365.492 * * * \\
(106,770.951)\end{array}$ & $\begin{array}{c}-242,973.178 * * \\
(107,576.336)\end{array}$ & $\begin{array}{c}-237,375.757 * * \\
(108,918.153)\end{array}$ \\
\hline car & & $\begin{array}{c}1,712.869 \\
(1,335.907)\end{array}$ & $\begin{array}{c}2,044.395 \\
(1,336.789)\end{array}$ & $\begin{array}{c}2,073.406 \\
(1,349.352)\end{array}$ \\
\hline $\mathrm{npf}$ & & $\begin{array}{l}-388,939.714 \\
(3638847.482)\end{array}$ & $\begin{array}{l}-1540431.823 \\
(3621824.195)\end{array}$ & $\begin{array}{l}-1965739.641 \\
(3620817.945)\end{array}$ \\
\hline grgdp & & & $\begin{array}{c}-30,594.131 \text { **** } \\
(11,606.165)\end{array}$ & $\begin{array}{c}-30,557.934 * * * \\
(11,552.209)\end{array}$ \\
\hline inflat & & & & $\begin{array}{c}5,536.215 \\
(3,607.714)\end{array}$ \\
\hline Constant & $\begin{array}{c}17,517.473 \\
(100,191.599)\end{array}$ & $\begin{array}{c}100,886.384 \\
(168,882.597)\end{array}$ & $\begin{array}{c}90,360.952 \\
(172,547.675)\end{array}$ & $\begin{array}{c}78,082.783 \\
(180,463.734)\end{array}$ \\
\hline Observations & 276 & 251 & 251 & 251 \\
\hline Number of id & 11 & 10 & 10 & 10 \\
\hline
\end{tabular}

FALAH Jurnal Ekonomi Syariah 
From the table above explains that efficiency give positive effect to deposit return. When added another variable, the efficiency still has a significant effect on deposit return, it can be said that the efficiency is really relavant.

\section{Conclusion}

Based on the analysis and discussion that has been described before then it can be concluded that Efficiency has a positive effect on deposit return. This indicates that the more efficient the bank, the greater the profit earned that will impact on the increase of profit sharing for investors (shahibul maal).

\section{References}

Berger, A.N. and L.J. Mester. 1997. Inside The Black Box: What Explains Differences In The Efficiencies of Financial Institutions? Journal of Banking \& Finance, 21, 895-947.

Berger, A.N., Humphrey, D.B. 1997. Efficiency of financial institutions: International survey and directions for future research. European Journal of Operations Research 98, 175-212.

Cevik, S., \& Charap, J. (2011). The behavior of conventional and Islamic Bank Deposit returns in Malaysia and Turkey. IMF Working Paper, WP/11/156.

Greuning, H.V. and Z. Iqbal, 2008. Risk analysis for islamic banks. Washington DC: The World Bank.

Hamza, H. 2015. Does investment deposit return in Islamic banks reflect PLS principle? Borsa_Istanbul Review 16-1 (2016) 32e42.

Jennifer, P dan Colin Thirtle. 2000. A Stochastic Frontier Approach to Firm Level Efficiency, Technological Change and Productivity During the Early Transition in Hungary, Journal of Comparative Economics.

Michel, A.H and Allexander P, Ljungqvist. 2000. Firm Value and Managerial ncentives: A Stochastic Frontier Approach, www.finance.ox.ac.uk

Mohamed H.M, Junaina, M. and Abdul, R.A.H. 2012. A comparative study on the level of efficiency between Islamic and conventional banking systems in Malaysia", International Journal of Islamic and Middle Eastern Finance and Management, Vol. 5 Issue: 1, pp.48-62A

Muhammad, A. 2004. Manajemen Dana Bank Syariah. Ekonisia: Yogyakarta

Syafira, R. 2014. Faktor-faktor yang Memengaruhi Tingkat Bagi Hasil Pada Produk Deposito Mudhorobah Bank Umum Syariah. [tesis]. Institut Pertanian Bogor 